\title{
EFFECT OF ZINC ACETATE AND MAGNESIUM SULFATE DIETARY SUPPLEMENTATION ON BROILER THIGH MEAT COLOUR, NUTRIENT COMPOSITION AND LIPID PEROXIDATION VALUES UNDER CONTINUOUS HEAT STRESS CONDITION
}

\author{
E. Norouzi ${ }^{1}$, M. Daneshyar ${ }^{1 \star}$, P. Farhoomand ${ }^{1}$, J. Aliakbarlu², F. Hamian ${ }^{2}$ \\ ${ }^{1}$ Department of Animal Science, Faculty of Agriculture, Urmia University, Urmia-57159-44931, Iran \\ ${ }^{2}$ Department of Food Hygiene and Quality Control, Faculty of Veterinary Medicine, Urmia University, \\ Urmia-57155-1177, Iran \\ •Corresponding author: m.daneshyar@urmia.ac.ir; mohsen_daneshyar@yahoo.com
}

\begin{abstract}
Four hundred and fifty one-day-old male broiler chicks (Ross 308) in 9 groups of 50 each $(3 \times 3$ factorial experiment) were randomly allocated to investigate the effects of different dietary levels of 0,30 and $60 \mathrm{mg} / \mathrm{kg}$ Zinc ( $\mathrm{Zn}$ ) and 0,300 and $600 \mathrm{mg} / \mathrm{kg}$ magnesium $(\mathrm{Mg})$ on thigh meat colour, nutrient composition and lipid peroxidation value in broiler chickens under heat stress. The birds were kept under a high temperature $\left(32 \pm 1^{\circ} \mathrm{C}\right)$ for $24 \mathrm{~h} /$ day for the first until the final day. At the end of the experiment (day 42), five birds per treatment were slaughtered. Then two pieces of the right thigh muscle per bird (upper part of the thigh muscle) were immediately collected for assessing the meat quality indices. The results of the present experiment showed that addition of $\mathrm{Zn}$ and $\mathrm{Mg}$ did not influence the ash, dry matter (DM) and ether extract (EE) contents of thigh meat $(\mathrm{P}>0.05)$, whereas the crude protein (CP) content of the thigh meat was increased when diet was supplemented with $\mathrm{Zn}(\mathrm{P}<\mathbf{0 . 0 5})$. Addition of $\mathrm{Zn}$ and $\mathrm{Mg}$ in diet did not change the mean lightness $(\mathrm{L})$ and redness (a) value in the thigh meat $(\mathrm{P}>0.05)$. Thigh yellowness $(\mathrm{b})$ value was increased by inclusion of $30 \mathrm{mg} / \mathrm{kg} \mathrm{Zn}$ alone or along with $600 \mathrm{mg} / \mathrm{kg} \mathrm{Mg}(\mathrm{P}<0.05)$. Furthermore, inclusion of $30 \mathrm{mg} / \mathrm{kg} \mathrm{Zn}$ in diet (at any level of $\mathrm{Mg}$ ) decreased the thigh thiobarbituric acid reactive substances $(\mathbf{P}<0.05)$.
\end{abstract}

Key words: thigh meat, thigh yellowness, crude protein, $\mathrm{pH}$, thiobarbituric acid reactive substances

High ambient temperature is a major problem in many parts of the world such as Iran, especially during summer. Exposure to high temperature has been reported to cause undesirable changes in meat quality of broilers (Aksit et al., 2006). It results in a decreased growth rate, meat yield and breast protein content of broilers (Yalcin 
et al., 2001). Heat stress during rearing is also one of the prominent antemortem stressors that results in a faster $\mathrm{pH}$ decline and pale colour of breast meat in birds such as turkey (McKee and Sams, 1997). McCurdy et al. (1996) reported that the mean lightness $\left(\mathrm{L}^{*}\right)$ value in the breast muscle of turkeys was the highest during the summer. Petracci et al. (2004) observed higher lightness ( $\left.\mathrm{L}^{*}\right)$ and lower redness $\left(a^{*}\right)$ and yellowness $\left(b^{*}\right)$ values for the breast muscle fillets of broilers reared in the summer than those reared in winter. Colour defects of raw and cooked poultry meat have been a problem in the poultry industry for many years. Increased chicken meat production and demand of food-store chains for standardized products caused the detailed evaluation of selected physical indicators, such as colour and tenderness of poultry meat (Abeni and Bergoglio, 2001). Nowadays, consumers pay special attention to meat colour and texture among the meat quality indices. Chicken meat contains an increased level of polyunsaturated fatty acids, which have a beneficial effect on the human health. A big demerit of this meat is the increased degradation of lipid fractions and its severity is positively correlated with the concentration of polyunsaturated fatty acids. Dietary unsaturated fat supplements increase the unsaturation degree and oxidation susceptibility of carcass fat in broilers (Daneshyar, 2012) leading to lipid peroxidation (LPO) caused by free radicals. The free radicals are involved in the uncontrolled chain reactions that primarily affect the phospholipids. The cell membrane phospholipids are particularly susceptible to the oxidative damage. It is widely established that a deficient as well as excessive intake of trace elements could cause an oxidative stress and lipid peroxidation in poultry (Surai, 2002), but the negative consequences of LPO can be overcome by the adequate supplementation of antioxidants to the diet. Some minerals such as zinc ( $\mathrm{Zn})$, and magnesium $(\mathrm{Mg})$ are strongly associated with the antioxidant defence of the organism. $\mathrm{Zn}$ is a micronutrient that participates in the antioxidant defence system. The $\mathrm{Zn}$ deficiency stimulates the oxidative damage through produced free radical action and alters the status of antioxidant enzymes and substances (Sahin et al., 2006). In quails, $\mathrm{ZnSO}_{4}$ or $\mathrm{Zn}$ picolinate supplementation (30 or $60 \mathrm{mg} / \mathrm{kg}$ ) have improved the carcass quality under heat stress temperature (Sahin et al., 2005). Sahin et al. (2005) also reported decreased serum malondialdehyde (MDA) concentrations (an indicator of lipid peroxidation) as a result of dietary $\mathrm{Zn}$ picolinate supplementation in heat-stressed quail. Sahin and Kucuk (2003) reported that 30 or $60 \mathrm{mg} / \mathrm{kg}$ of $\mathrm{Zn}$ decreased serum and liver MDA levels in heat stressed chickens. $\mathrm{Mg}$ is the other required mineral for good health in humans and animals (Kucuk, 2008). The Mg deficiency is also related to oxidative stress. $\mathrm{Mg}$ is one of the most abundant divalent cations in living cells and plays a vital role in many cellular processes. D'Souza et al. (1998) reported that pigs supplemented with Mg-aspartate-hydrochloride had less pale meat with higher $\mathrm{pH}$ value and lower drip loss percentage compared to the control group. No report is available regarding the effect of $\mathrm{Mg}$ and $\mathrm{Zn}$ on meat quality and lipid peroxidation of broiler chickens reared under heat stress condition. The objective of the present study was, therefore, to determine the effect of the dietary supplementation with zinc acetate and magnesium sulfate on broiler thigh meat colour, nutrient composition and lipid peroxidation values under continuous heat stress condition. 


\section{Material and methods}

\section{Birds and housing}

Four hundred and fifty day-old male broiler chicks (Ross 308) purchased from a commercial hatchery, were weighed on arrival and were randomly assigned to 9 treatment groups consisting of 5 replicate pens with 10 birds each in a $3 \times 3$ factorial design. The birds of different treatments had the same mean body weight at day one of age. The experiment was conducted under appropriate animal care regulations. The research proposal was reviewed and approved by the Animal Care Committee of Urmia University. The birds were kept under a continuous high temperature condition $\left(32 \pm 1^{\circ} \mathrm{C}\right)$ for $24 \mathrm{~h} /$ day from the first until the final day. Average ambient relative humidity inside the house was $40 \%$. Twenty-three hours of lighting and an hour dark was provided per day (Aviagen guidelines). The birds were fed a starter mash diet until day 21 of age followed by a grower mash diet afterwards (from day 22 to day 42 of age). The basal starter and grower diets were formulated according to the Ross requirements (Aviagen Company) guideline. Ingredients and chemical composition of the basal diet are shown in Table 1. Feed and water were provided ad libitum. The birds were fed either a basal diet supplemented with 0,30 and $60 \mathrm{mg}$ of $\mathrm{Zn} / \mathrm{kg}$ or 0 , 300 and $600 \mathrm{mg}$ of $\mathrm{Mg} / \mathrm{kg}$ of diet. Mineral premix already contained $85 \mathrm{mg} \mathrm{Zn}$ and no $\mathrm{Mg}$ per $\mathrm{kg}$ of feed. Hence three levels of 85, 115 and $145 \mathrm{mg} \mathrm{Zn/kg}$ were provided in the experimental diets. Source of $\mathrm{Zn}$ was zinc acetate $\left(\mathrm{C}_{4} \mathrm{H}_{6} \mathrm{O}_{4} \mathrm{Zn}\right.$, Applichem, Germany) whereas magnesium sulfate $\left(\mathrm{MgSO}_{4}\right.$, Merck, Germany) was used as the source of $\mathrm{Mg}$. Hence, small amounts of the basal diet were first mixed with the respective amounts of $\mathrm{Zn}$ and $\mathrm{Mg}$ as a small batch, and then with a larger amount of the basal diet until the total amount of the respective diets was homogeneously mixed. At the end of the experiment (day 42), five birds per treatment (one per replicate pen) were randomly selected and slaughtered. Two pieces of right thigh muscle per bird (upper part of the thigh muscle) were immediately collected in plastic bags and kept at $20^{\circ} \mathrm{C}$ for assessing the meat quality indices. One piece of thigh meat was used for determination of $\mathrm{pH}$ and nutrient composition (dry matter, ash, ether extract and crude protein). Thigh meat colour index was assessed from the surface area of the other piece.

\section{Meat quality measurements}

For thiobarbituric acid reactive substances (TBARS) determination, firstly $10 \mathrm{~g}$ of meat sample were weighed into a 50-ml test tube and $1 \mathrm{ml}$ of $0.1 \%$ BHT was added. Then $35 \mathrm{ml}$ of $5 \%$ trichloroacetic acid (TCA) were added and the meat samples were homogenized (Ultra-Turrax T-25, Janke \& Kunkel IKA-Labortechnik, Staufen, Germany) at 13,500 rpm for $30 \mathrm{~s}$. After filtering, $5 \mathrm{ml}$ of the filtrate and $5 \mathrm{ml}$ thiobarbituric acid solution $(0.02 \mathrm{mM})$ were added to the test tube. Tubes were heated in a boiling water bath for 1 hour at $100^{\circ} \mathrm{C}$, cooled and then absorbance was measured at $532 \mathrm{~nm}$ against a blank containing $5 \mathrm{ml}$ of TCA and $5 \mathrm{ml}$ of TBA solution. TBARS values were expressed as mg per $\mathrm{kg}$ of sample (Ulu, 2004).

The colour of thigh meat was measured by a chromameter (CR-400, Japan). Meat colour ranged from light, $\mathrm{L}^{*}>53$; to normal, $48<\mathrm{L}^{*}<51$; and dark, $\mathrm{L}^{*}<46$. Colour categorization was based on 3 points of every meat in triplicate after slaughter. 
For the $\mathrm{pH}$ determination, approximately $2.5 \mathrm{~g}$ of ground thigh meat was homogenized in $25 \mathrm{~mL}$ of an iodoacetate solution ( $5 \mathrm{mM}$ sodium iodoacetate, $150 \mathrm{mM}$ potassium chloride, and the $\mathrm{pH}$ adjusted to 7.0 with potassium hydroxide) for $30 \mathrm{~s}$, and the $\mathrm{pH}$ of the homogenate was determined using a $\mathrm{pH}$ meter (TitroLine Easy, Schott Instruments, Mainz, Germany) that was calibrated at $\mathrm{pH} 4.0$ and 7.0.

Table 1. Ingredients and calculated chemical analyses of the diets $(\mathrm{g} / \mathrm{kg}$, fresh basis)

\begin{tabular}{|c|c|c|}
\hline Ingredients (g/kg) & Starter $(0-21 \mathrm{~d})$ & $\operatorname{Grower}(22-42 \mathrm{~d})$ \\
\hline Maize & 319.0 & 328.7 \\
\hline Soya bean meal (CP $440 \mathrm{~g} / \mathrm{kg})$ & 395.6 & 337.8 \\
\hline Wheat & 200.0 & 250.0 \\
\hline Soya oil & 38.0 & 42.0 \\
\hline Dicalcium phosphate & 21.0 & 21.5 \\
\hline Limestone & 11.0 & 8.6 \\
\hline Salt & 3.7 & 3.4 \\
\hline DL-Methionine (98\%) & 3.8 & 0.8 \\
\hline L-Lysine (HCL) & 2.9 & 2.2 \\
\hline Trace minerals premix ${ }^{a}$ & 2.5 & 2.5 \\
\hline Multi-vitamin premix $^{\mathrm{b}}$ & 2.5 & 2.5 \\
\hline \multicolumn{3}{|l|}{ Calculated chemical analysis } \\
\hline Metabolizable energy $(\mathrm{MJ} / \mathrm{kg})$ & 12.14 & 12.52 \\
\hline Crude protein $(\mathrm{g} / \mathrm{kg})$ & 220 & 200 \\
\hline Calcium (g/kg) & 10 & 9.0 \\
\hline Available phosphorus (g/kg) & 4.5 & 4.5 \\
\hline L-Lysine (g/kg) & 14.3 & 12.4 \\
\hline Threonine (g/kg) & 8.5 & 7.7 \\
\hline Isoleucine (g/kg) & 9.7 & 8.8 \\
\hline Valine (g/kg) & 10.8 & 9.8 \\
\hline Tryptophan (g/kg) & 2.9 & 2.6 \\
\hline Arginine $(\mathrm{g} / \mathrm{kg})$ & 14.5 & 12.7 \\
\hline Methionine + Cystine $(\mathrm{g} / \mathrm{kg})$ & 10.7 & 7.2 \\
\hline Sodium $(g / k g)$ & 1.5 & 1.5 \\
\hline
\end{tabular}

aProvided per kg of ration; copper $10 \mathrm{mg}$, iron $50 \mathrm{mg}$, manganese $100 \mathrm{mg}$, zinc $85 \mathrm{mg}$, selenium 0.2 and iodine $1.0 \mathrm{mg}$.

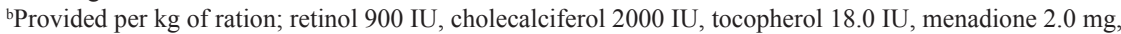
thiamine $1.8 \mathrm{mg}$, riboflavin $6.6 \mathrm{mg}$, pyridoxine $3.0 \mathrm{mg}$, cyanocobalamin $0.015 \mathrm{mg}$, niacin $30 \mathrm{mg}$, pantothenic acid $10 \mathrm{mg}$, folic acid $1.25 \mathrm{mg}$, choline $500 \mathrm{mg}$ and biotin $0.1 \mathrm{mg}$.

Meat moisture was determined using the vacuum-oven method according to the Association of Official Analytical Chemists (AOAC, 1999). The ground meat samples were dried for $48 \mathrm{~h}$ in a vacuum-oven $(23 \mathrm{kPa})$ at $98^{\circ} \mathrm{C}$ and cooled to room temperature in a desiccator prior to taking final weights. 


\section{Statistical analyses}

The data were analysed in a $3 \times 3$ factorial arrangement of treatments based on a completely randomized design with five replicates per treatment. The pen was used as the experimental unit. The results of the experiments were analysed by ANOVA using the GLM procedure of SAS software (SAS Company, version 9.1) to assess the effects of different levels of $\mathrm{Zn}, \mathrm{Mg}$ and their interactions on thigh meat colour, nutrient composition and lipid peroxidation. The univariate test in SAS (SAS Institute Inc., Cary, NC, USA) was used to assess the normality of all data. Differences among treatments means were determined using Tukey multiple range test at $\mathrm{P}<0.05$ significance level.

\section{Results}

\section{Thigh meat nutrient composition}

The effects of dietary $\mathrm{Zn}$ and $\mathrm{Mg}$ supplementation on thigh meat nutrient composition of broilers are shown in Table 2. Dietary supplementation with different levels of $\mathrm{Zn}$ and $\mathrm{Mg}$ did not influence the thigh ash, DM and EE contents $(\mathrm{P}>0.05)$. Moreover, no significant interactions were observed between the $\mathrm{Zn}$ and $\mathrm{Mg}$ for the above mentioned parameters $(\mathrm{P}>0.05)$. $\mathrm{Zn}$ dietary supplementation had a significant effect on thigh meat $\mathrm{CP}$ value $(\mathrm{P}<0.05)$. Supplementation with $30 \mathrm{mg} / \mathrm{kg}$ of $\mathrm{Zn}$ along with $600 \mathrm{mg} / \mathrm{kg}$ of $\mathrm{Mg}$ to diet increased the thigh meat CP content compared to control diet. Thigh meat $\mathrm{pH}$ value was affected by $\mathrm{Mg}$ dietary supplementation $(\mathrm{P}<0.05)$. Dietary supplementation with $600 \mathrm{mg} / \mathrm{kg} \mathrm{Mg}$ without supplemental $\mathrm{Zn}$ increased thigh $\mathrm{pH}$ compared to the supplementation with lower levels of $\mathrm{Mg}$ (0 and $300 \mathrm{mg}$ ) $\mathrm{kg}$ ) along with $30 \mathrm{mg} / \mathrm{kg}$ of $\mathrm{Zn}$.

\section{Thigh meat colour index and lipid peroxidation}

Table 3 shows the supplementation effects of $\mathrm{Zn}$ and $\mathrm{Mg}$ on thigh meat colour index and lipid peroxidation values. Dietary addition of $\mathrm{Zn}$ or $\mathrm{Mg}$ did not change either the lightness (L) or the redness (a) of thigh meat $(\mathrm{P}>0.05)$. Moreover, no interactive effect was observed between the $\mathrm{Zn}$ and $\mathrm{Mg}$ for these two parameters $(\mathrm{P}>0.05)$. On the other hand, both the $\mathrm{Zn}$ and $\mathrm{Mg}$ affected thigh meat yellowness (b) value $(\mathrm{P}<0.05)$. Supplementation with $30 \mathrm{mg} / \mathrm{kg} \mathrm{Zn}$ alone or along with $600 \mathrm{mg} / \mathrm{kg} \mathrm{Mg}$ increased thigh yellowness (b) value as compared to the control treatment group $(\mathrm{P}<0.05)$. Thigh meat TBARS values were only affected by the $\mathrm{Zn}$ supplementation $(\mathrm{P}>0.05)$, as $30 \mathrm{mg} / \mathrm{kg}$ of $\mathrm{Zn}$ reduced the thigh TBARS content at any level of $\mathrm{Mg}$ in comparison to the control group. 


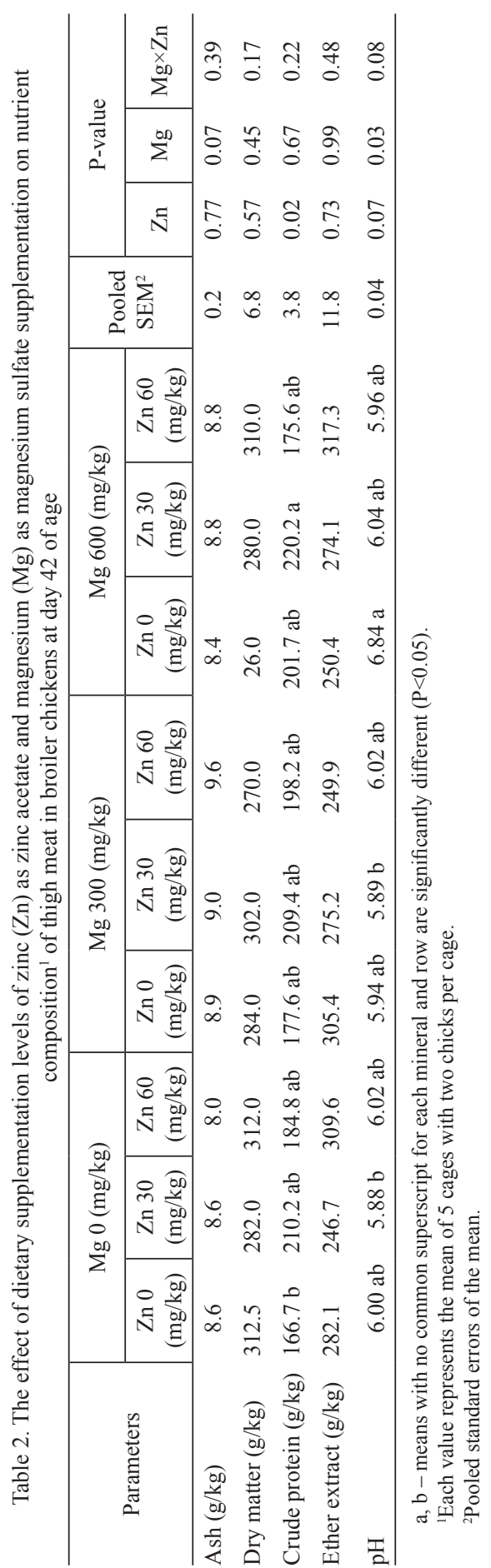




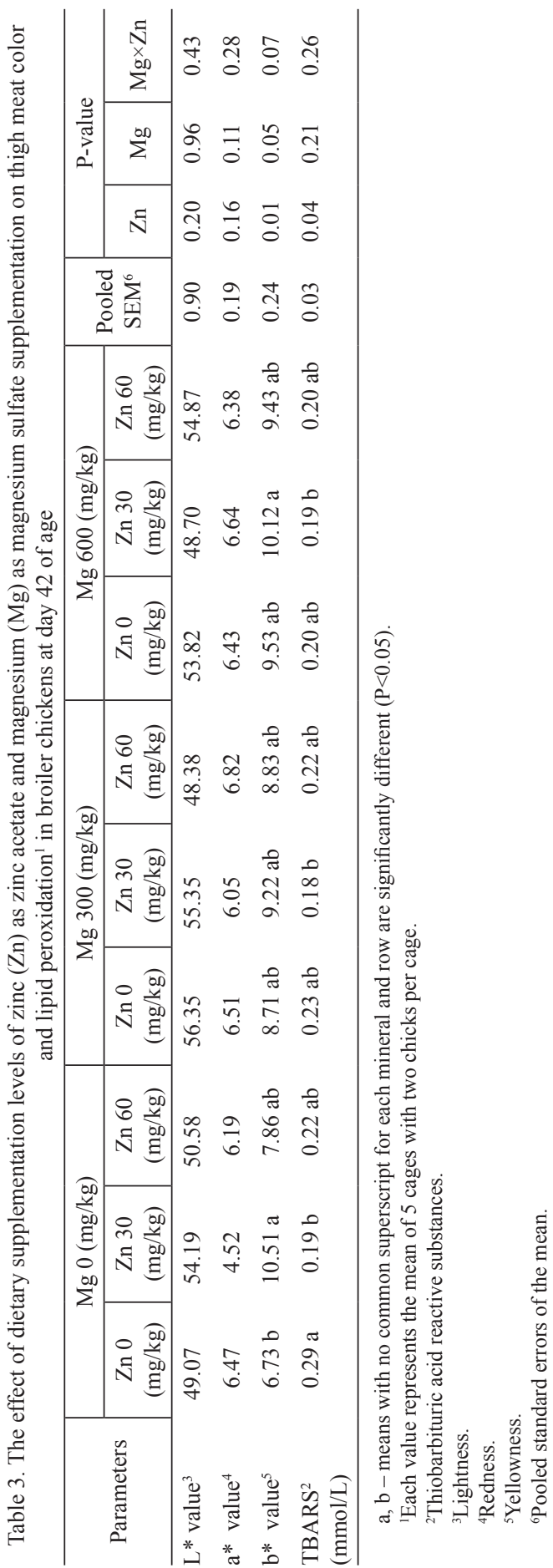




\section{Discussion}

In the current experiment, supplementation with $30 \mathrm{mg}$ of $\mathrm{Zn}$ per $\mathrm{kg}$ of the basal diet (providing $115 \mathrm{mg} / \mathrm{kg}$ ) enhanced the thigh meat CP. One possible reason of the increased thigh CP of these birds could be the improved digestibility of nutrients, especially proteins, due to $\mathrm{Zn}$ supplementation. It has been recognized that heat stress increases the excretion of minerals such as zinc, copper, and manganese (Belay and Teeter, 1996). The $\mathrm{Zn}$ positively affects feed utilization through its action in the metabolism of carbohydrates, lipids and proteins (MacDonald, 2000). The digestibility of proteins, fats, and starch decreased with exposure of broiler chickens to high temperatures. In addition, activities of trypsin, chymotrypsin and amylase are decreased at a temperature of $32^{\circ} \mathrm{C}$ (Hai et al., 2000). $\mathrm{Zn}$ has a protective role on pancreatic tissue against oxidative damage and it may help the pancreas to function properly including secretions of digestive enzymes, thus improving digestibility of nutrients. Higher performance of $\mathrm{Zn}$ dietary supplemented birds (especially feed intake) could be the other reason for higher thigh CP compared to the control group. Better body weight gain, feed intake and feed conversion ratio for broiler chickens fed $30 \mathrm{mg} /$ $\mathrm{kg}$ of $\mathrm{Zn}$ have been reported elsewhere (Nourozi et al., 2013). The Zn deficiency is characterized by decreased feed intake, decreased growth, low circulating levels of growth hormone $(\mathrm{GH})$ and insulin-like growth factor-I, and decreased hepatic production of insulin-like growth factor-I, GH receptor, and $\mathrm{GH}$ binding protein in animals (MacDonald, 2000).

Furthermore, $\mathrm{Mg}$ inclusion in diet had an effect on the thigh $\mathrm{pH}$ in the current study. Generally, $\mathrm{pH}$ value is a direct reflection of muscle acid content, and affects the shear force, drip loss and colour in meat. Muscle $\mathrm{pH}$ variation is also related to glycogenolysis, and increased catecholamine secretion in response to an acute stressor just prior to slaughter increases glycogen breakdown and the rate of $\mathrm{pH}$ decline post-slaughter while the carcass temperature is still high, resulting in pale, soft, exudative (PSE) meat (Briskey and Wismer-Pedersen, 1961). D'Souza et al. (1998) stated that the sedative function of $\mathrm{Mg}$ reduced the stress-induced catecholamine secretion and then inhibited glycogen breakdown and glycolysis. Guo et al. (2003) reported the highest thigh meat $\mathrm{pH}$ after the dietary supplementation with $2.0 \mathrm{~g} / \mathrm{kg}$ proteinate of $\mathrm{Mg}$ in broiler diets. Holm and Fletcher (1997) observed that broilers held at $29^{\circ} \mathrm{C}$ during crating had lower ultimate $\mathrm{pH}$ compared to broilers held at 7 and $18^{\circ} \mathrm{C}$. Stress before slaughter can lead to increased muscle glycogen breakdown and glycolysis after slaughter, and then the increased muscle lactic acid lowers the $\mathrm{pH}$ of meat.

The mechanism that associates dietary $\mathrm{Mg}$ with post mortem $\mathrm{pH}$ could be explained by the roles of $\mathrm{Mg}$ in some enzymes involved in glycogen metabolism, such as pyruvate kinase and ATP-Mg-dependent phosphatase. Pyruvate kinase is unique among kinases in its requirement for enzyme-bound cations, normally $\mathrm{Mg}^{2+}$ and $\mathrm{K}^{+}$. The enzyme is found in all cells and tissues during glycolysis and is of particular importance for controlling the flux from fructose-1, 6-bisphosphate through to pyruvate (Muirhead et al., 1986). ATP-Mg-dependent phosphatases have broad substrate specificity, responsible for the major dephosphorylation reactions of the en- 
zymes involved in the hormonal control glycogen metabolism (Vandenheede et al., 1981).

In addition, the results of our study indicated that dietary supplementation with $600 \mathrm{mg} / \mathrm{kg}$ of $\mathrm{Mg}$ and $30 \mathrm{mg} / \mathrm{kg}$ of $\mathrm{Zn}$ increased the yellowness (b) value in the thigh meat. Colour is a major criterion that can be used by consumers to judge meat quality. Hot weather conditions (such as summer) have been reported to increase the lightness (L) and to decrease the redness (a) and yellowness (b) in the breast muscle fillets of broilers (Petracci et al., 2004). Barbut (1993) reported that lightness (L) had the highest correlation of the $\mathrm{L}^{*}, \mathrm{a}^{*}, \mathrm{~b}^{*}$ colour parameters with PSE-like conditions. The yellowness (b) of meat colour during heat stress is related to the reactive oxygen radicals (ROS) and lipid peroxidation. Heat stress increases ROS, possibly by the disruption of the electron transport assemblies of the membrane. A moderate increase of ROS promotes cell proliferation and differentiation, whereas excessive amounts of ROS due to an elevated ROS production or to a decline of ROS-scavenging capacity can cause severe oxidative damage to lipids, proteins and DNA (Boonstra and Post, 2004). Consistent with the results of the current experiment, Liu et al. (2011) detected increased $b^{*}$ value of thigh muscles after 60,120 and $180 \mathrm{mg} / \mathrm{kg}$ of $\mathrm{Zn}$ dietary supplementation. Saenmahayak et al. (2007) have shown that $\mathrm{Zn}$ supplementation affects the meat quality through reduced cooking loss and darker fillets, which may be correlated with a lower incidence of pale, soft and exudative meat. This effect may be due to the ability of $\mathrm{Zn}$ to bind myoglobin and increase its oxygenation. The $\mathrm{Zn}$ also inhibits mitochondrial respiration and decreases the production of free radicals by acting as an antioxidant, thus facilitating the maintenance of meat colour (Powell, 2000).

The thigh TBARS was reduced by the dietary supplementation with $30 \mathrm{mg} / \mathrm{kg}$ $\mathrm{Zn}$ in the present study. Oxidation of lipid components in muscle tissues is the major cause of quality deterioration and short shelf life after slaughter (Guo et al., 2003). TBARS or malondialdehyde (MDA) are the soluble degraded product of lipids that can be widely used to reflect the extent of lipid oxidation in meat (Raharjo and Sofos, 1993). Heat stress causes oxidative stress, and TBARS production is increased (Halliwell and Gutteridge, 1989). Sahin and Kucuk (2003) reported that 30 or $60 \mathrm{mg} / \mathrm{kg}$ of $\mathrm{Zn}$ decreased serum and liver MDA levels in heat-stressed birds. In heat-stressed quail, Kucuk (2008) also showed that both $\mathrm{Zn}$ and Mg supplementations decreased plasma MDA levels. Zinc may play a key role in suppression of free radicals because it is a cofactor of the main antioxidative enzyme $\mathrm{Cu}-\mathrm{Zn}-\mathrm{SOD}$ and it also inhibits the NADPH-dependent lipid peroxidation (Prasad and Kucuk, 2002). It prevents lipid peroxidation via inhibiting glutathione depletion as well. Due to the ability to replace $\mathrm{Fe}$ and $\mathrm{Cu}$ from binding sites, $\mathrm{Zn}$ can compete with these transition metals to bind to the cell membrane and decrease the production of free radicals and thus exert a direct antioxidant action (Oteiza et al., 1996).

Based on the results of the present study showing the highest yellowness (b value) and CP, and the lowest TBARS content in thigh meat of $30 \mathrm{mg} / \mathrm{kg} \mathrm{Zn}$ fed birds, it was concluded that inclusion of $30 \mathrm{mg} / \mathrm{kg} \mathrm{Zn}$ in diet can improve the meat quality of broiler chickens under heat stress. 


\section{References}

A be ni F., B ergolgio G. (2001). Characterization of different strains of broiler chicken by carcass measurements, chemical and physical parameters and NIRS on breast muscle. Meat Sci., 57: 133-137.

A ks it S., Yalcin S., Ozkan S., Metin K., Ozdemir D. (2006). Effects of temperature during rearing and crating on stress parameters and meat quality of broilers. Poultry Sci., 85: $1867-1874$

AOAC (1999). Official Methods of Analysis, 15th Ed. Association of Official Analytical Chemists. Washington, DC.

B a rbut S. (1993). Color measurements for evaluating the pale soft exudative (PSE) occurrence in turkey meat. Food Res. Int., 26: 39-43.

B e l a y T., T e e t e r R. (1996). Effects of environmental temperature on broiler mineral balance partitioned into urinary and fecal loss. Br. Poultry Sci., 37: 423-433.

B o onstra J., P o s t J.A. (2004). Molecular events associated with reactive oxygen species and cell cycle progression in mammalian cells. Gene, 337: 1-13.

B riskey E.J., Wis mer-P edersen J. (1961). Biochemistry of pork muscle structure. I. Rate of anaerobic glycolysis and temperature change versus the apparent structure of muscle tissue. J. Food Sci., 26: 297-305.

D ' S o u za D.N., Warn er R.D., L e u ry B.J., D u n s h e a F.R. (1998). The effect of dietary magnesium aspartate supplementation on pork quality. J. Anim. Sci., 76: 104-109.

Dane shy a r M. (2012). The effect of dietary turmeric on antioxidant properties of thigh meat in broiler chickens after slaughter. Anim. Sci. J., 83: 599-604.

Gu o Y., Z hang G., Yu a n J., N i e W. (2003). Effects of source and level of magnesium and vitamin E on prevention of hepatic peroxidation and oxidative deterioration of broiler meat. Anim. Feed Sci. Technol., 107: 143-150.

H a i L., R ong D., Z hang Z.Y. (2000). The effect of thermal environment on the digestion of broilers. J. Anim. Physiol. Anim. Nutr., 83: 57-64.

H a 11 i w e 11 B.E., G u t t e r i d g e J.M.C. (1989). Lipid peroxidation: A radical chain reaction. In: Free radicals in biology and medicine. 2nd ed. Oxford University Press, New York, pp. 188-218.

Holm C.G.P., F le t c h e r D.L. (1997). Antemortem holding temperatures and broiler breast meat quality. J. Appl. Poult. Res., 6: 180-184.

K u c u k O. (2008). Zinc in a combination with magnesium helps reducing negative effects of heat stress in quails. Biol. Trace Elem. Res., 123: 144-153.

Li u L., Lu S.F., Li L.Y., Zhang L., Xi L., Zhang K.Y., Lu o X.G. (2011). Effects of supplemental zinc source and level on growth performance, carcass traits, and meat quality of broilers. Poultry Sci., 90: 1782-1790.

M a c D o n a ld R.S. (2000). The role of zinc in growth and cell proliferation. J. Nutr., 130 (5S Suppl.): $1500 \mathrm{~S}-1508 \mathrm{~S}$.

M c Curdy R.D., B a rbut S., Qu in to n M. (1996). Seasonal effect on pale soft exudative (PSE) occurrence in young turkey breast meat. Food Res. Int., 29: 363-366.

M c ke e S.R., S a m s A.R. (1997). The effect of seasonal heat stress on rigor development and the incidence of pale, exudative turkey meat. Poultry Sci., 76: 1616-1620.

Muirhe ad H., Clayden D.A., B arford D., L ori mer C.G., F o the rgil1-Gilmore L.A., Schiltz E., Schmitt W. (1986). The structure of cat muscle pyruvate kinase. EMBO J., 5: $475-481$.

Norouzi E., Daneshyar M., Farhoom and P. (2013). Short communication. Dietary supplementation effects of zinc acetate and magnesium sulfate on performance and antioxidant status of broilers under continuous heat stress. Span. J. Agric. Res., 11: 127-131.

O te i z a P.L., O 1 i n K.L., F r a g a C.G., K e e n C.L. (1996). Oxidant defense systems in testes from Zn deficient rats. P. Soc. Exp. Biol. Med., 213: 85-91.

P e tra c c i M., B e t t i M., C a va n i C. (2004). Color variation and characterization of broiler breast meat during processing in Italy. Poultry Sci., 83: 2085-2092.

P ow el1 S.R. (2000). The antioxidant properties of zinc. J. Nutr., 130: 1447S-1454S.

Pra s a d A.S., K u c u k O. (2009). Zinc in cancer prevention. Cancer Metast. Rev., 2: 291-295. 
Raharjo S., S of o s J.N. (1993). Methodology for measuring malonaldehyde as a product of lipid peroxideation in muscle tissues: a review. Meat Sci., 35: 145-169.

$\mathrm{S}$ a e $\mathrm{m}$ m a h a y a B., B i $1 \mathrm{~g}$ i 1 i S.F., H e s s J.B. (2007). Influence of complexed trace mineral supplementation on carcass grade and meat quality of broilers processed at 42 and 56 days of age. Poultry Sci., 86 (Suppl. 1): 278.

S a h in K., K u cuk O. (2003). Zinc supplementation alleviates heat stress in laying Japanese quail. J. Nutr., 33: 2808-2811.

S ah in K., S mith M.O., Onderc i M., S ah in N., Gursu M.F., Kucuk O. (2005). Supplementation of zinc from organic or inorganic source improves performance and antioxidant status of heat-distressed quail. Poultry Sci., 84: 882-887.

Sahin K., Onderci M., S ah in N., Gursu F., Yild iz N., Avc i M., Ku cuk O. (2006). Responses of quail to dietary vitamin $\mathrm{E}$ and zinc picolinate at different environmental temperatures. Anim. Feed Sci. Technol., 129: 39-48.

S u r a i P.F. (2002). Selenium in poultry nutrition 1. Antioxidant properties, deficiency and toxicity. World Poultry Sci. J., 58: 333-347.

U 1 u H. (2004). Evaluation of three 2-thiobarbituric acid methods for the measurement of lipid oxidation in various meats and meat products. Meat Sci., 67: 683-687.

Vandenheede J.R., Yang S.D., Merleveede W. (1981). Rabbit skeletal muscle protein phosphatase(s) - identity of phosphorylase and synthase phosphatase and interconversion to the ATP-Mg-dependent enzyme form. J. Biol. Chem., 256: 5894-5900.

Yalc in S., O zk an S., T u r k m u t L., S i e g e l P.B. (2001). Responses to heat stress in commercial and local broiler stocks. I. Performance traits. Br. Poultry Sci., 42: 149-152.

Received: 29 VII 2013

Accepted: 26 XI 2013 